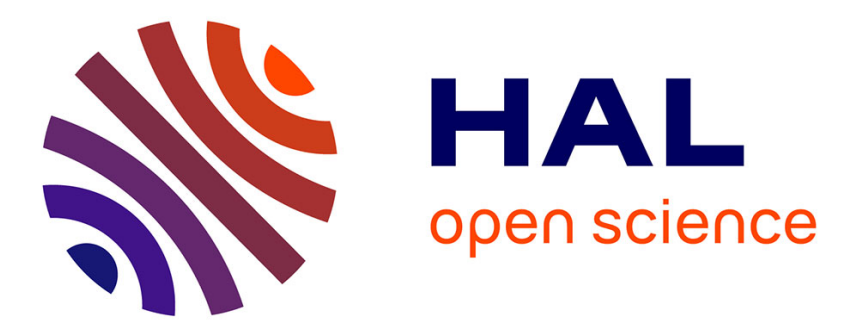

\title{
Influence of inoculum and anode surface properties on the selection of Geobacter-dominated biofilms
}

Audrey S. Commault, Frédéric Barrière, Laure Lapinsonnière, Gavin Lear, Solène Bouvier, Richard J Weld

\section{- To cite this version:}

Audrey S. Commault, Frédéric Barrière, Laure Lapinsonnière, Gavin Lear, Solène Bouvier, et al.. Influence of inoculum and anode surface properties on the selection of Geobacter-dominated biofilms. Bioresource Technology, 2015, 195, pp.265-272. 10.1016/j.biortech.2015.06.141 . hal-01174903

HAL Id: hal-01174903

https://hal-univ-rennes1.archives-ouvertes.fr/hal-01174903

Submitted on 24 Nov 2015

HAL is a multi-disciplinary open access archive for the deposit and dissemination of scientific research documents, whether they are published or not. The documents may come from teaching and research institutions in France or abroad, or from public or private research centers.
L'archive ouverte pluridisciplinaire HAL, est destinée au dépôt et à la diffusion de documents scientifiques de niveau recherche, publiés ou non, émanant des établissements d'enseignement et de recherche français ou étrangers, des laboratoires publics ou privés. 


\title{
Influence of inoculum and anode surface properties on
}

the selection of Geobacter-dominated biofilms

Audrey S Commault ${ }^{a, *}$, Frédéric Barrière ${ }^{b}$, Laure Lapinsonnière ${ }^{b}$, Gavin Lear ${ }^{c}$, Solène Bouvier $^{d}$, Richard J Weld ${ }^{a}$

${ }^{a}$ Lincoln Agritech Ltd., Engineering Drive, Lincoln University, Christchurch 7640, New Zealand.

${ }^{\mathrm{b}}$ Institut des Sciences Chimiques de Rennes, UMR CNRS 6226, Université de Rennes 1, France.

${ }^{c}$ School of Biological Sciences, The University of Auckland, Auckland 1010, New Zealand.

${ }^{\mathrm{d}}$ Ecole Nationale Supérieure de Chimie et de Physique de Bordeaux, France.

\begin{abstract}
This study evaluated the impact of inoculum source and anode surface modification (carboxylate $-\mathrm{COO}$ and sulphonamide $-\mathrm{SO}_{2} \mathrm{NH}_{2}$ groups) on the microbial composition of anode-respiring biofilms. These two factors have not previously been considered in detail. Three different inoculum sources were investigated, a dry aerobic soil, brackish estuarine mud and freshwater sediment. The biofilms were selected using a poised anode $(-0.36 \mathrm{~V}$ vs $\mathrm{Ag} / \mathrm{AgCl})$ and acetate as the electron donor in a three-electrode configuration microbial fuel cell (MFC). Population profiling and cloning showed that
\end{abstract}

${ }^{*}$ Corresponding author.

Univ Technol Sydney, Plant Funct Biol \& Climate Change Cluster, 15 Broadway, Sydney, NSW 2007, Australia. Phone: +61 42258 7001.E-mail: audrey.commault@gmail.com. 
all biofilms selected were dominated by Geobacter sp., although their electrochemical properties varied depending on the source inoculum and electrode surface modification. These findings suggest that Geobacter sp. are widespread in soils, even those that do not provide a continuously anaerobic environment, and are better at growing in the MFC conditions than other bacteria.

Keywords: microbial fuel cell; electroactive biofilm; soils; electrode surface; population profiling.

\section{Introduction}

Exoelectrogens are found in anaerobic sediments and soils where they have access to both reduced organic compounds, for use as electron donors, and insoluble inorganic electron acceptors including manganese and iron oxides (Lovley, 1993; Weber et al., 2006). Many locations meet these requirements while varying in other environmental parameters. Previous work has confirmed the presence of exoelectrogenic bacteria in various different environments including freshwater sediments (Chae et al., 2009; Holmes et al., 2004), marine sediments (Bond et al., 2002; Tender et al., 2002), saltmarshes (Holmes et al., 2004), anaerobic sludge from potato processing (Rabaey et al., 2004), wastewater treatment plants (Kan et al., 2011; Lefebvre et al., 2010), and recently in mangrove swamp sediments (Salvin et al., 2012). Geobacteraceae are usually the predominant microorganisms colonizing the anodes introduced in such environments, with a higher abundance of Desulfuromonas species in marine and saltmarsh sediments; while in freshwater sediments, Geobacter species are the most common Geobacteraceae (Holmes et al., 2004). Following the Baas-Becking 
hypothesis (1934) that "Everything is everywhere, but the environment selects", we should expect to select for exoelectrogenic biofilms dominated by Geobacteraceae whatever the inoculum used. Indeed, Yates et al. (2012) showed that the predominance of Geobacter sp. in acetate-fed MFCs (Microbial Fuel Cells) was independent of the inoculum source, after testing three inocula (two wastewaters from different locations and an anaerobic bog sediment). However, other researchers found that the inoculum makes a difference in the selection of anode-respiring biofilm in MFCs (Miceli et al., 2012). Miceli et al. (2012) tested thirteen samples from locations around the world and placed them in MFCs with electrodes poised at $-0.30 \mathrm{~V}$ vs $\mathrm{Ag} / \mathrm{AgCl}$ in acetate medium. Only 7 out of 13 samples produced sufficient current $\left(>1.59 \mathrm{~A} / \mathrm{m}^{2}\right)$ after 21 days of selection. They found that bacteria related to the genus Geobacter dominated only two of the seven biofilm communities producing a high current; the other biofilm communities contained different known and/or novel exoelectrogenic bacteria (Miceli et al., 2012). Few studies have looked at the effect of inoculum source on the composition of exoelectrogenic biofilms selected in MFCs either with or without fixed anode potentials. To bring more consistency in the results, it is recommended to test inocula in MFCs held at the same fixed potential (e.g., $-0.08 \mathrm{~V}$ vs SHE), as the anode potential is likely to influence the composition of the anodic biofilm (Commault et al., 2013). The inocula tested in previous studies are typically from rich, moist anaerobic environments likely to contain Geobacter sp. In this study three very different inocula are tested: a saline estuary mud; a freshwater sediment; and a dry, exposed, low fertility basalt/loess soil thought to be unlikely to contain Geobacter sp. Each inoculum was placed in an MFC with the anode held at $-0.36 \mathrm{~V}$ vs $\mathrm{Ag} / \mathrm{AgCl}(-0.08 \mathrm{~V}$ vs $\mathrm{SHE})$ as an electron acceptor and provided acetate as an electron donor. The selected anodic biofilms were 
compared for current production, biofilm/electrode interaction, and dominant microbial community composition.

We also investigated the impact of electrode surface properties on the selection of electro-active biofilms in MFCs. The anode surface chemical and physical properties affect bacterial adhesion and electron transfer process between bacteria and electrodes (Guo et al., 2013). Modification of electrode surfaces aiming to improve the efficiency of MFCs has recently emerged as a new field of research (Kumar et al., 2013; Wei et al., 2011). Although some studies have proven that certain anode modifications lead to more efficient MFCs (Lapinsonniere et al., 2013; Picot et al., 2011), the influence of surface modifications for biofilm growth and maintenance is not well understood. In this study, the effect of two different chemical groups: negatively charged carboxylate group (-COO-$)$ and sulfonamide group $\left(-\mathrm{SO}_{2} \mathrm{NH}_{2}\right)$ neutral at physiological $\mathrm{pH}$ were tested on electro-active biofilms selected in MFCs using the same inoculum and same anode potential $(-0.36 \mathrm{~V}$ vs $\mathrm{Ag} / \mathrm{AgCl})$. The sulfanilamides are characterized by their lipophilicity and their amine groups partly protonated at $\mathrm{pH}$ 7. Note however that the amine group is lost in the modification process so that the resulting modifier bears a neutral charge (phenylsulfonamide). The lipophilicity of sulfanilamides favours their interactions with the lipid bilayer of the bacterial cell membrane and the polymeric lipophilic compounds of EPS (extracellular polymeric substances). The presence of phenylsulfonamide at the electrode surface is therefore likely to encourage the attachment of bacteria via lipophilic attachment. The carboxylates $\left(-\mathrm{COO}^{-}\right)$are negatively charged at $\mathrm{pH} 7\left(\mathrm{pKa}\left(-\mathrm{COOH} /-\mathrm{COO}^{-}\right) \sim 4\right)$, which could potentially repulse bacteria. The bacterial community composition of biofilms selected on modified electrodes was investigated along with their electrochemical properties. 
This paper examines whether two independent factors, inoculum source and electrode surface modification, could alter the composition and electrochemical properties of anodic biofilms selected in MFCs. This question is of importance for the discovery of new anode-respiring bacteria and new metabolic pathways for higher current production in MFC. The two factors were tested independently starting with three different microbial inoculum sources.

\section{Methods}

\subsection{Electrode modification procedures}

Carboxylate and sulfonamide groups were grafted onto graphite rod electrodes using the electrochemical reduction of aryl diazonium salts, as described by Picot et al. (2011). The process involved two steps, the formation of aryl diazonium salts from their corresponding amines followed by in-situ electro-reduction of the diazonium, by cyclic voltammetry with monitoring of the charge consumed in the process to control the amount of molecules grafted on the electrode (Picot et al., 2011). Diazonium salts were generated in situ in a total volume of $75 \mathrm{~mL}$ of acidic aqueous medium $(0.1 \mathrm{M} \mathrm{HCl})$ containing the starting aryl amine (4 $\mathrm{mM}$ of 4 -aminobenzoic acid for $-\mathrm{COO}^{-}$and $2 \mathrm{mM}$ of 4-aminobenzenesulfonamide for $-\mathrm{SO}_{2} \mathrm{NH}_{2}$ ) and sparged with argon for 10 min to remove oxygen. Then sodium nitrite $\left(\mathrm{NaNO}_{2}\right)$ was added at a final concentration of

$10 \mathrm{mM}$. The mix was kept on ice in the dark to stabilize the generated aryl diazonium salt. This solution served as the electrolyte for the modification of the previously sandpapered graphite electrode by electrochemical reduction of the diazonium salts using a potentiostat (model EA164 QuadStat). A three-electrode cell configuration was used with an $\mathrm{Ag} / \mathrm{AgCl}, \mathrm{NaCl}(3 \mathrm{M})$ reference electrode (0.28 V vs SHE, BASI 
Electroanalytical Chemistry, MF-2052) and a second graphite electrode as the counter electrode, as described by Commault et al. (2013). Electrochemical reduction of the diazonium salts was achieved by recurrent cyclic voltammetry sweeps starting at zerocurrent potential (around $+0.2 \mathrm{~V}$ vs $\mathrm{Ag} / \mathrm{AgCl}$ ) and decreasing to $-0.2 \mathrm{~V}$ vs $\mathrm{Ag} / \mathrm{AgCl}$. Several scans at a rate of $0.05 \mathrm{~V} . \mathrm{s}^{-1}$ were needed to reach a global charge density (Q) of $15-20 \mathrm{mC} . \mathrm{cm}^{-2}$ (projected anode area of $5.81 \mathrm{~cm}^{2}$ ). To probe the effect of the modification on the electrode properties, cyclic voltammetry was performed at a scan range of $-0.1 \mathrm{~V}$ to $0.4 \mathrm{~V}$ and a scan rate of $0.1 \mathrm{~V} \cdot \mathrm{s}^{-1}$ in a solution of potassium ferricyanide $\mathrm{K}_{3}\left[\mathrm{Fe}(\mathrm{CN})_{6}\right]: 2 \mathrm{mM}$ of ferricyanide, $0.1 \mathrm{M} \mathrm{KCl}$ and $10 \mathrm{mM}$ of phosphate buffer $\mathrm{pH}$ 7. The voltammograms obtained were compared to an unmodified graphite electrode.

\subsection{Anode-respiring biofilm growth and selection}

All the anode-respiring biofilms presented in this paper were selected in $100 \mathrm{~mL}$ MFCs as previously described by Commault et al. (2013). The anode potentials were maintained at $-0.36 \mathrm{~V}$ versus $\mathrm{Ag} / \mathrm{AgCl}$ (i.e. $-0.08 \mathrm{~V}$ vs $\mathrm{SHE}$ ) using a three-electrode arrangement. The counter electrode (carbon cloth, Fuel Cell Earth LLC, Ma, USA) was separated from the anolyte by an Ultrex CMI-7000 cation-exchange membrane (Membranes International Inc., NJ, USA) in a chamber containing $0.1 \mathrm{M}$ phosphate buffer ( $\mathrm{pH}$ 7.5). The anode, a (modified or unmodified) graphite rod of $5.81 \mathrm{~cm}^{2}$, was maintained at a fixed potential by a 4-channel potentiostat (model EA164 QuadStat) connected to an e-corder 1621 unit (eDAQ Pty Ltd, NSW, AUS). The same inoculum was used for the experiment comparing the effects of two chemical groups grafted on anodes. The $\mathrm{COO}^{-}$and $\mathrm{SO}_{2} \mathrm{NH}_{2} \mathrm{MFCs}$ were both inoculated with $50 \mathrm{~mL}$ of watersaturated soil collected in Lincoln (Christchurch, NZ). For the experiment comparing 
the effect of three different inocula on the growth and selection of anodic biofilms, $50 \mathrm{~mL}$ of soils from diverse environments were added to three different MFCs with unmodified working electrodes. The inocula were referred to as (i) "Crater Rim" (CR) a dry soil collected on the hillside of a Banks Peninsula walking track (Canterbury, NZ); (ii) "Church Bay" (CB) a wet saline estuary mud (Canterbury, NZ); and (iii) "Halswell River" (R) a wet soil from the bed of a freshwater stream (Canterbury, NZ). Once inoculate, the $100 \mathrm{~mL}$ MFCs were filled with a minimal medium (pH 7.5) containing $15 \mathrm{mM}$ of acetate (composition described in Commault et al. (2013)) previously sparged with nitrogen $\left(<10 \mathrm{ppm}\right.$ of $\left.\mathrm{O}_{2}\right)$ gas for $10 \mathrm{~min}$. The biofilms were left to develop on the constant-voltage anodes for 29 days (66 days for "Crater Rim") at room temperature $\left(21^{\circ} \mathrm{C}\right)$ without mixing. The biofilms were fed $50 \mathrm{~mL}$ of fresh, nitrogen-sparged, acetate medium (15 mM acetate, $\mathrm{pH} 7.5)$ every two or three days in batch mode, corresponding to hydraulic retention times of 96 hours (4 days) and 145 hours (6 days) respectively. Current measurements were made every $10 \mathrm{~min}$ to follow the formation of anoderespiring biofilms. The experiment comparing the different inocula was not replicated due to the limited number of channels of the potentiostat.

\subsection{Electrochemical analysis}

Prior to each electrochemical analysis, the totality of the used medium $(100 \mathrm{~mL})$ was replaced in each anode chamber with fresh acetate medium $(15 \mathrm{mM})$ to ensure that the $\mathrm{pH}$ and the chemical oxygen demand were the same for all the MFCs. Power density curves were plotted 29 days after selection under acetate saturation using the potentiostat (model EA164 QuadStat) and a two-electrode cell configuration by coupling the reference electrode with the counter electrode and poising the anode versus the counter/reference electrode, as described by Picot et al. (2011). Ten different 
voltages were applied for $300 \mathrm{~s}$ from open circuit potential to near short-circuit potential, while monitoring the steady state current. The internal resistance of system $\left(\mathrm{R}_{\text {int }}\right)$ is obtained at maximum power and was calculated using equation (1).

$R_{i n t}=\frac{P_{\text {Max }}}{t^{2}} \quad$ (1), with $\mathrm{P}_{\max }$ the maximum power and I the corresponding

current.

The electronic interactions at the interface of the biofilm/electrode were measured by cyclic voltammetry 29 days after selection (66 days for "Crater Rim"). Cyclic voltammetry was performed using a potentiostat (EC epsilon, BASi, IN, USA) at $1 \mathrm{mV} . \mathrm{s}^{-1}$ in turnover conditions and at $25 \mathrm{mV} . \mathrm{s}^{-1}$ in non-turnover conditions at potentials ranging from $-0.6 \mathrm{~V}$ to $0.1 \mathrm{~V} v \mathrm{Ag} / \mathrm{AgCl}$. The cyclic voltammogram of the electrolyte from the "Crater Rim" MFC was performed using a clean graphite rod electrode of $5.81 \mathrm{~cm}^{2}$ and the same parameters as in non-turnover conditions, after 10 min of bubbling with nitrogen $\left(<10 \mathrm{ppm}\right.$ of $\left.\mathrm{O}_{2}\right)$ gas.

\subsection{DNA extraction}

DNA was extracted at the end of the experiment using an UltraClean ${ }^{\mathrm{TM}}$ Soil DNA Isolation kit (MO Bio Laboratories Inc., CA, USA). The extracted DNA was quantified by spectrophotometry (NanoDrop ${ }^{\circledR}$ ND-1000) and its quality examined by electrophoresis on $0.7 \%$ agarose gel. The DNA extracts were then stored at $-20^{\circ} \mathrm{C}$ for further analyses. We used ARISA (automated ribosomal intergenic spacer analysis) for our analysis of bacterial communities because of the relative ease, cost-effectiveness and reproducibility of the method. ARISA is a fast method to visualize the taxon richness of a biofilm. In the case of biofilms with low taxon richness, cloning was performed to identify the species dominating the biofilms. 


\subsection{Population profiling: Automated Ribosomal Intergenic Spacer Analysis} (ARISA)

ARISA is a semi-quantitative molecular DNA fingerprinting technique targeting the intergenic region of bacterial $16 \mathrm{~S}$ and $23 \mathrm{~S}$ rRNA genes. As length of the intergenic region varies across taxa, these data can provide a profile of community structure within each sample. ARISA of bacterial DNA was performed as previously described by Commault et al. (2013). The results were visualised in GeneMapper software (version 3.7, Applied Biosystems Ltd.) and processed in Excel. The similarities between the bacterial community data among samples were compared using a Bray Curtis similarity matrix (Legendre \& Legendre, 1998) and visualised in the form of a cluster dendogram in PRIMER6 software (version 6.1.12, Primer-E Ltd., Plymouth, UK) (Commault et al., 2013; Lear et al., 2008).

\subsection{Cloning and sequencing}

The 16S rRNA genes of the extracted DNA were amplified using the universal primers B342If (5'-CTA CGG GIG GCI GCA GT-3') and U806Ir (5'-GGA CTA CCI GGG TIT CTA A-3') (Hori et al., 2006), except for the "Crater Rim" sample where the $16 \mathrm{~S}$ rRNA genes were amplified using the universal primers PB36 (5'-AGR GTT TGA TCM TGGCTC AG-3') and PB38 (5'-GKT ACC TTG TTA CGA CTT-3') (Lear et al., 2009). The BIOTAQ ${ }^{\mathrm{TM}}$ PCR kit (Bioline), and the following PCR conditions were used: (i) $94^{\circ} \mathrm{C}$ for $3 \mathrm{~min}$; (ii) 30 cycles of $94^{\circ} \mathrm{C}$ for $60 \mathrm{~s}, 50^{\circ} \mathrm{C}$ for $60 \mathrm{~s}, 72^{\circ} \mathrm{C}$ for $70 \mathrm{~s}$, and then (iii) $72^{\circ} \mathrm{C}$ for $10 \mathrm{~min}$. Once amplified, the $16 \mathrm{~S}$ rRNA fragments were ligated into pCR2.1 vectors using a TA Cloning ${ }^{\circledR}$ Kit (Invitrogen, USA) and transformed into One Shot ${ }^{\circledR}$ E. coli TOP10F' $\mathrm{CaCl}_{2}$ competent cells, according to the manufacturer's protocol (Invitrogen, USA). Isolated clones were selected on Luria Bertani (LB) agar plates 
containing $100 \mu \mathrm{g} \cdot \mathrm{mL}^{-1}$ of ampicillin. The inserts of clones were sequenced on a 3130XL Capillary Genetic Analyser (Applied Biosystems Ltd., Melbourne, Australia) in both reverse and forward directions using the plasmid specific primers M13f (5' CTG GCC GTC GTT TTA-3') and M13r (5'-CAG GAA ACA GCT ATG AC-3'). The forward and reverse sequences were aligned and corrected with ChromasPro software (Technelysium Pty Ltd, Brisbane, Australia). The consensus sequences were compared with the nucleotide collection (nr/nt) of the National Center for Biotechnology Information (www.ncbi.nlm.nih.gov/BLAST/) using the megablast algorithm to confirm the likely identity of bacteria based on 16S rRNA gene sequence fragments.

\subsection{Statistical analysis}

Welch's t-tests were calculated using the excel function 'T.TEST'. Two-tailed t-tests were performed assuming unequal variance. At $\mathrm{p}<0.05$, we interpreted the data as being significantly different.

\section{Results and Discussion}

\subsection{Effect of different inocula on the selection of Geobacter-dominated biofilms}

Three MFCs were set-up with unmodified electrodes and inoculated with three different soil samples. No current was observed immediately after inoculation (Figure 1) allowing time for the bacterial community to adapt to the MFC conditions. A positive (oxidation) current was first observed in the MFCs inoculated with "Church Bay" (CB) and "River" (R) soils approximately 14 days after inoculation, followed by "Crater Rim" (CR) MFC after 28 days. The "Church Bay" soil was collected in an estuary where the salinity was likely higher than the salinity of the growth medium, but it did not seem to impact the start-up time of the MFC compared to the freshwater inoculum. 
The start-up time of "Crater Rim" MFC was twice as long as the start-up times of the MFCs inoculated with "River" or "Church Bay" soils. When Miceli et al. (2012) tried to select anode-respiring bacteria from thirteen diverse inocula around the world using a poised anode $(-0.30 \mathrm{~V}$ vs $\mathrm{Ag} / \mathrm{AgCl})$ and acetate as the electron donor in a MFC, only half of them produced high current densities ( $>1.5 \mathrm{~A} / \mathrm{m}^{2}$, anode) after 21 days of selection. They explained that their results might be due to factors such as the suitability of the media for the growth of the organisms present in the inocula, varying capacities for electrode respiration, or differing methods of biofilm formation between different organisms (Miceli et al., 2012). These factors could explain the longer start-up time of the "Crater Rim" communities too. The soil collected from the hillside of "Crater Rim" walking track was very dry compared to "Church Bay" and "River" soils, and was likely to contain mainly aerobic bacteria. Three potential reasons could explain the longer start up times seen with the "Crater Rim" inoculum: (i) there may be fewer bacteria capable of anode-respiration present in the inoculum, so it takes longer to multiply up to the numbers needed to produce a measurable current; (ii) the inoculum may contain less diversity amongst the anode-respiring bacteria than is present in the other inocula and therefore may lack species or strains well adapted for growing in the MFC conditions; (iii) "Crater Rim" bacteria may not have been exposed to anaerobic conditions for some time, and so it takes them longer to physiologically adapt to the anaerobic conditions or to form appropriate syntrophic associations that allow them to effectively colonize the electrode (physiological adaption). The results presented here, do not exclude any of these possibilities. It is plausible that the slow start-up of "Crater Rim" MFCs was due to a combination of all three reasons. 
The current delivered by "Church Bay" and "River" MFCs was higher than 1.7 A.m ${ }^{-2}$ towards the end of the experiment, while the maximal current density generated by “Crater Rim" MFC was only 0.13 A.m ${ }^{-2}$ after 60 days of growth. Surprisingly, the current density doubled to reach $0.25 \mathrm{~A} \cdot \mathrm{m}^{-2}$ when the biofilm was fed minimal medium without acetate after 66 days of operation (Figure 1). This is paradoxical as acetate was the only electron donor in the medium. It is possible that the high acetate concentration had an inhibitory effect on the electron transfer of the "Crater Rim" biofilm. Feeding the biofilm with acetate-depleted medium would have diluted the acetate left in the electrolyte to an optimal concentration for the biofilm. To have a better understanding of the mechanism of electron transfer in the "Crater Rim" biofilm, cyclic voltammetry and sequencing results were then considered.

The turnover voltammograms of "Church Bay" and "River" biofilms, performed after 29 days of enrichment, showed a sigmoidal catalytic wave characteristic of acetate oxidation by Geobacter sp. at the potential of outer membrane cytochromes with a midpoint potential around $-0.4 \mathrm{~V}$ vs $\mathrm{Ag} / \mathrm{AgCl}$ (Figure 2a,b). The "Church bay" and "River" voltammograms showed a complex pattern (Figure 2a,b), suggesting that two different pathways were involved in the electron transfer. At low potentials (between 0.4 to $-0.3 \mathrm{~V}$ ys $\mathrm{Ag} / \mathrm{AgCl}$ ) the electron transfer was favoured by one pathway, and was then shifted to another pathway at potentials higher than $-0.3 \mathrm{~V}$. This dynamic potentialdependent change between two electron transport pathways was recently described by Yoho et al. (2014) in anode biofilm of Geobacter sulfurreducens. The "Crater Rim" biofilm had a distinct turnover voltammogram revealing the presence of a redox system with a reduction peak at $-0.35 \mathrm{~V}$ and an oxidation peak at $-0.05 \mathrm{~V}$ vs $\mathrm{Ag} / \mathrm{AgCl}\left(\mathrm{E}_{1 / 2}=-\right.$ $0.15 \mathrm{~V})$. The same redox system was observed on non-turnover voltammograms, as the 
biofilm kept on producing the mediator even in the absence of acetate. This redox system was not detected in the electrolyte (Figure 2c) and can be assigned to either a redox active species produced by the "Crater Rim" biofilm or an outer membrane redox protein. In any case, this redox system does not seem to be involved in efficient direct or mediated electron transfer between the biofilm and the anode.

The dominant 16S rRNA genes of the three MFC biofilms were sequenced at the end of the experiment to confirm the presence of Geobacter sp. within their bacterial communities. Of 12 clones isolated from "Church Bay" biofilm, 11 were most similar to Geobacter psychrophilus with $96 \%$ of identity (Figure 3). The same Geobacter species dominated the "River" biofilm as 8 clones out of 9 were similar at $96 \%$ to Geobacter psychrophilus (Figure 3). When aligned together, the 16S rRNA fragments of "Church Bay" and "River" biofilms most similar to Geobacter psychrophilus differed by one base at position 118 (Thymine for "River" and Adenine for "Church Bay"), suggesting that both biofilms may have been dominated by different isolates of Geobacter psychrophilus (initially present in the inoculum). This could explain the different voltammogram shapes of the two biofilms (Figure 2a,b). The biofilm enrichment with psychrophilic microorganisms might be a consequence of the inoculum and/or the enrichment temperature. G. psychrophilus was previously shown to dominate anodic communities in MFCs operating at about $20^{\circ} \mathrm{C}$ (Liu et al., 2012; Lu et al., 2011), while other species such as G. sulfurreducens may predominate at temperature higher than $30^{\circ} \mathrm{C}$ (Miceli et al., 2012; Yoho et al., 2014), that would not allow a psychrophilic organism to thrive. The selective temperature is therefore likely to affect the composition of the anodic communities. 
The "Crater Rim" biofilm was also dominated by Geobacter sp. (10 clones out of 17). Among the Geobacter species identified, 6 were similar at 97\% to Geobacter psychrophilus. The second group was similar at $99 \%$ to Desulfovibrio intestinalis (3 clones out of 17). Clones most closely related to Proteiniphilum sp., Pseudomonas sp. Clostridium sp. and Alcaligenes sp. were each represented by a single DNA sequence (Figure 3). Amongst the species present (differing from Geobacter sp.), one or more may be responsible for the redox active species detected by cyclic voltammetry in Figure 2c.

It is interesting that three very different environments from separate geographical localities: a wet saline environment by an estuary; a wet freshwater environment by a lowland river and dry soil on a hillside, provided exactly the same dominant species after MFC selection. It suggests that Geobacter psychrophilus is widespread in soils, even those that do not provide a continuously anaerobic environment, and is better at growing in MFCs in these conditions than other bacteria present. Therefore, $G$. psychrophilus is "everywhere", as predicted by Baas-Becking (1934), but the environment does select where different strains will thrive. Even though the soil samples were collected in very different overall environments, each sample likely contained many micro-environments, many of which were identical. Consequently, they may be inhabited by the same bacteria. These results differed from Miceli et al. (2012) who found that bacteria related to the genus Geobacter dominated only two of the seven biofilms selected from diverse inocula and producing a high current on cylindrical graphite rods poised at $-0.30 \mathrm{~V}$ vs $\mathrm{Ag} / \mathrm{AgCl}$. The voltammograms of the seven biofilms all showed sigmoidal waves, suggesting that direct electron-transfer mechanisms were involved. None of their seven biofilms showed mediated electron transfer as observed 
for "Crater Rim" (Miceli et al., 2012), maybe because none were selected from an aerobic dry soil. The unique Geobacter-dominated community of "Crater Rim" biofilm suggests that the potential capacity for anode respiration is widespread even in environments that we might expect would be frequently exposed to oxygen.

\subsection{Effect of electrode surface modifications on the selection of Geobacter-}

\section{dominated biofilms}

Two MFCs were set-up per treatment using a three-electrode configuration with the modified working electrode (- $\mathrm{COO}^{-}$or $-\mathrm{SO}_{2} \mathrm{NH}_{2}$ ) poised at $-0.36 \mathrm{~V}$ against the $\mathrm{Ag} / \mathrm{AgCl}$ reference electrode. The same inoculum, water-saturated soil, was used for all the MFCs and they produced a similar amount of current over the course of the selection phase. The biofilms growing on the $\mathrm{SO}_{2} \mathrm{NH}_{2}$ electrode had the fastest start-up time with a positive current after $2.8 \pm 1.1$ days, compared to $6.3 \pm 1.3$ days for the $\mathrm{COO}^{-}$biofilms. Although the $\mathrm{SO}_{2} \mathrm{NH}_{2}$ modification led to the fastest start-up time, it had the lowest maximum power output, while the biofilm attached to the $\mathrm{COO}^{-}$electrode delivered the highest power density (Figure 4). The MFCs with a modified electrode had a maximum power density higher than the one with an unmodified electrode.

Modifying an electrode with $\mathrm{SO}_{2} \mathrm{NH}_{2}$ groups is likely to have a beneficial effect on the initial adhesion of bacteria to the electrode as the exoelectrogenic bacteria colonized the $\mathrm{SO}_{2} \mathrm{NH}_{2}$ electrode faster than the $\mathrm{COO}^{-}$electrode according to their start-up times. The sulfonamides are known to have antibacterial properties when free in solution (Florestano \& Bahler, 1952). Their activity depends on their lipophilicity, which determines their ability to get inside the bacterial cell, and their ionization at physiological $\mathrm{pH}$. Once inside the cell, they act as competitive inhibitors of 
dihydropteroate synthase (DHPS), an enzyme present exclusively in bacterial cells, resulting in the depletion of folic acid stores leading to failure of purine and thymine nucleotides biosynthesis and eventually inhibiting DNA synthesis (Valderas et al., 2008). In this case, the sulfonamides groups did not have an antibacterial activity as they were grafted on the electrode surface. However, their lipophilicity may have accelerated the attachment of bacterial cells to the electrode by penetrating the bilayer structures of phospholipids of the outer-membrane. This would have resulted in the more rapid development of the anode-respiring biofilm and so the production of electricity, explaining the faster start-up time. However, the biofilms growing on $\mathrm{SO}_{2} \mathrm{NH}_{2}$ did not perform as well as the $\mathrm{COO}^{-}$biofilms as shown by the lower power density (Figure 4).

It was anticipated that the carboxylates groups would repulse negatively charged bacteria due to their negative charge at $\mathrm{pH} 7$ and so slow down the start-up time or even the current production (Picot et al., 2011). The $\mathrm{COO}^{-} \mathrm{MFCs}$ had a start-up time twice as long as the $\mathrm{SO}_{2} \mathrm{NH}_{2}$ MFCs, but it showed the highest power density and the highest catalytic current (Figure 5), suggesting that the electron transfer from the biofilm to the electrode was very efficient. These results are at variance with those of Picot et al. (2011) who showed that a negatively charged electrode surface led to a drop of power densities compared to an unmodified electrode. However, bacteria poorly colonized their electrode modified with benzylcarboxylate groups. Picot et al. (2011) explained their results by an electrostatic repulsion between the electrode surface and negative charge of bacteria including Geobacter sp. Unlike Picot et al. (2011), Kuzume et al. (2013) found that carboxyl groups interact with the outermost cytochromes of Geobacter sulfurreducens, facilitating the heterogeneous electron transfer at the 
microorganism/electrode interface. In this system, we noted that the $\mathrm{COO}^{-}$fuel cell had the lowest internal resistance with $422 \Omega$ against $463 \Omega$ for the unmodified electrode and $495 \Omega$ for the $\mathrm{SO}_{2} \mathrm{NH}_{2}$ MFC. This may be explained in part by the affinity of carboxylate groups with the outer-membrane cytochromes facilitating the electron transfer from the biofilm to the electrode.

The turnover voltammograms performed after 29 days of selection showed a sigmoid catalytic wave for the two modified electrodes. This wave is characteristic of acetate oxidation via the catalytic action of the biofilm grown on the electrode surface (Figure 5). The $\mathrm{COO}^{-}$anode had a significantly lower midpoint potential of acetate oxidation at $-0.406 \pm 0 \mathrm{~V}$ against $-0.394 \pm 0.001 \mathrm{~V}$ vs $\mathrm{Ag} / \mathrm{AgCl}$ for the $\mathrm{SO}_{2} \mathrm{NH}_{2}$ electrodes. This is consistent with a relatively faster electron transfer at the carboxylate modified electrode.

ARISA was performed at the end of the experiment, after 29 days of incubation, to check if the different electrode surface modifications selected for different bacterial communities. The two biofilms were dominated by a small number of taxa, as shown by the small number of peaks on their ARISA electropherograms (Figure S1a,b). They both had similar dominant bacterial communities with the same four dominant peaks present in each of their ARISA profiles at $619 \mathrm{bp}, 633 \mathrm{bp}, 679 \mathrm{bp}$ and $703 \mathrm{bp}$. Those peaks were previously observed in the ARISA profiles of Geobacter-dominated biofilms selected at $-0.36 \mathrm{~V}$ vs $\mathrm{Ag} / \mathrm{AgCl}$ (Commault et al., 2013). In spite of being selected on different electrode surfaces, the biofilms had similar dominant communities. The analysis of the ARISA profile data using the Bray Curtis similarity matrix revealed that while no large difference amongst the dominant taxa was observed in the two types of biofilms, there were nevertheless consistent differences in community structure 
(Figure S1c). The Bray Curtis similarity matrix takes more base pairs into account than can be visually detected with an electropherogram, and showed that the biofilms from the same electrode modification were more similar to each other than to biofilms from the other modification. The results from the ARISA profiles and the similarity matrix suggested that there were small but consistent differences in the dominant communities of the $\mathrm{COO}^{-}$and $\mathrm{SO}_{2} \mathrm{NH}_{2}$ biofilms.

All 16S rRNA gene clones (13/13) of the biofilms selected on the $\mathrm{SO}_{2} \mathrm{NH}_{2}$ modified electrodes were identified as being similar at $96 \%$ to Geobacter psychrophilus. As the $\mathrm{COO}^{-}$biofilms were dominated by bacterial OTU with the same ITS length as $\mathrm{SO}_{2} \mathrm{NH}_{2}$ biofilms (Figure S1a), we assumed that $\mathrm{COO}^{-}$biofilms were dominated by Geobacter psychrophilus too.

We anticipated that changing the electrode surface properties could select for different bacterial communities. For instance, a negatively charged electrode surface at $\mathrm{pH} 7$ (e.g., - $\mathrm{COO}^{-}$modification) should electrostatically repulse bacteria and may result in different bacterial communities than neutral electrode surface modification (e.g., $\mathrm{SO}_{2} \mathrm{NH}_{2}$ modification). The electrode modifications did not influence the composition of the most dominant species in the selected biofilms, as their ARISA profiles were similar. However, consistent subtle changes in community composition were detected by Bray Curtis similarity analysis of ARISA profile data. These results are different from the results of Picot et al. (2011), who found using fluorescence in situ hybridization (FISH, probe Geo1A), that biofilms selected from domestic wastewater on anode modified with benzylcarboxylate groups (functional group - $\mathrm{COO}^{-}$) had less bacterial cells than biofilms selected on positively charged surfaces (modified with aryl diazonium salts or 4-benzyl triphenylphosphonium diazonium), and only few of them 
belonged to the Geobacter subgroup (Picot et al. 2011). However, Guo et al. (2013) showed that differences in biofilm communities were attributed to differences in hydrophilicity or hydrophobicity of electrode surfaces more than to differences in the charge of the electrode modification groups. They showed that glassy carbon surfaces modified with $-\mathrm{CH}_{3},-\mathrm{OH},-\mathrm{SO}_{3}{ }^{-}$, or $-\mathrm{N}^{+}\left(\mathrm{CH}_{3}\right)_{3}$ functional groups by electrochemical reduction of aryl diazonium salts all led to the selection of biofilms dominated by Geobacter sp., with the positively charged and hydrophilic surfaces being more selective to electro-active microbes. Their FISH results showed that at the electrode interface, the relative Geobacter abundance on the hydrophobic surface $\left(-\mathrm{CH}_{3}\right)$ was only about half of that of the biofilms on hydrophilic surfaces $\left(-\mathrm{N}^{+}\left(\mathrm{CH}_{3}\right)_{3},-\mathrm{OH}\right.$, and $\mathrm{SO}_{3}{ }^{-}$). Hence, Guo et al. (2013) hypothesized that the surface hydrophobicity affects the initial attachment of Geobacter sp., and so the subsequent biofilm development. The two functional groups tested in the present study probably increased the hydrophilicity of the graphite electrode surface. The increase of hydrophilicity compared to the unmodified electrode, would have favoured the attachment of Geobacter sp.

\section{Conclusion}

The different inocula and electrode surface modifications tested all selected for Geobacter-dominated biofilms. However, there were major differences in the biofilm communities selected from the different inocula and small but consistent differences in the dominant communities of the $\mathrm{COO}^{-}$and $\mathrm{SO}_{2} \mathrm{NH}_{2}$ biofilms. The two factors also affected the electrochemical properties of the biofilms.

Because of the dominance of Geobacter sp. in electroactive biofilms, the use of different inocula or anode surface modifications is unlikely to lead to the discovery of 
new anode-respiring bacteria, but it could shed light on new metabolic pathways for higher current production in MFC.

\section{Acknowledgements}

This work was supported by funding from the New Zealand Ministry of Business, Innovation and Employment (MBIE), contract LVLX0802. A. Commault was supported by a Lincoln Agritech Ltd PhD scholarship. We also thank the France-New Zealand Dumont d'Urville exchange program (2013-2014) for support. 


\section{References}

1. Baas-Becking, L.G.M. 1934. Geobiologie of inleiding tot de milieukunde. Van Stockum \& Zoon, The Hague, the Netherlands: W.P.

2. Bond, D.R., Holmes, D.E., Tender, L.M., Lovley, D.R. 2002. Electrode-reducing microorganisms that harvest energy from marine sediments. Science, 295(5554), 483-485.

3. Chae, K.-J., Choi, M.-J., Lee, J.-W., Kim, K.-Y., Kim, I.S. 2009. Effect of different substrates on the performance, bacterial diversity, and bacterial viability in microbial fuel cells. Bioresource Technology, 100(14), 3518-3525.

4. Commault, A.S., Lear, G., Packer, M.A., Weld, R.J. 2013. Influence of anode potentials on selection of Geobacter strains in microbial electrolysis cells. Bioresource Technology, 139, 226-234.

5. Commault, A.S., Lear, G., Weld, R. 2015. Maintenance of Geobacter-dominated biofilms in microbial fuel cells treating synthetic wastewater. Bioelectrochemistry.

6. Florestano, H.J., Bahler, M.E. 1952. A critical comparison of the antibacterial properties of commonly employed sulfonamides. Journal of the American Veterinary Medical Association, 121(909), 474-7.

7. Guo, K., Freguia, S., Dennis, P.G., Chen, X., Donose, B.C., Keller, J., Gooding, J.J., Rabaey, K. 2013. Effects of Surface Charge and Hydrophobicity on Anodic Biofilm Formation, Community Composition, and Current Generation in Bioelectrochemical Systems. Environmental Science \& Technology, 47(13), 7563-7570.

8. Holmes, D.E., Bond, D.R., O'Neill, R.A., Reimers, C.E., Tender, L.R., Lovley, D.R. 2004. Microbial communities associated with electrodes harvesting electricity from a variety of aquatic sediments. Microbial Ecology, 48(2), 178-190.

9. Hori, T., Haruta, S., Ueno, Y., Ishii, M., Igarashi, Y. 2006. Dynamic transition of a methanogenic population in response to the concentration of volatile fatty acids in a thermophilic anaerobic digester. Applied and Environmental Microbiology, 72(2), 16231630.

10.Kan, J., Hsu, L., Cheung, A.C.M., Pirbazari, M., Nealson, K.H. 2011. Current Production by Bacterial Communities in Microbial Fuel Cells Enriched from Wastewater Sludge with Different Electron Donors. Environmental Science \& Technology, 45(3), 1139-1146.

11.Kumar, G.G., Sarathi, V.G.S., Nahm, K.S. 2013. Recent advances and challenges in the anode architecture and their modifications for the applications of microbial fuel cells. Biosensors \& Bioelectronics, 43, 461-475.

12.Kuzume, A., Zhumaev, U., Li, J.F., Fu, Y.C., Fueg, M., Esteve-Nunez, A., Wandlowski, T. 2013. An in-situ surface electrochemistry approach toward whole-cell studies: Charge transfer between Geobacter sulfurreducens and electrified metal/electrolyte interfaces through linker molecules. Electrochimica Acta, 112, 933-942.

13.Lapinsonniere, L., Picot, M., Poriel, C., Barriere, F. 2013. Phenylboronic Acid Modified Anodes Promote Faster Biofilm Adhesion and Increase Microbial Fuel Cell Performances. Electroanalysis, 25(3), 601-605.

14.Lear, G., Anderson, M.J., Smith, J.P., Boxen, K., Lewis, G.D. 2008. Spatial and temporal heterogeneity of the bacterial communities in stream epilithic biofilms. Fems Microbiology Ecology, 65(3), 463-473.

15.Lear, G., Niyogi, D., Harding, J., Dong, Y.M., Lewis, G. 2009. Biofilm Bacterial Community Structure in Streams Affected by Acid Mine Drainage. Applied and Environmental Microbiology, 75(11), 3455-3460.

16.Lefebvre, O., Nguyen, T.T.H., Al-Mamun, A., Chang, I.S., Ng, H.Y. 2010. T-RFLP reveals high beta-Proteobacteria diversity in microbial fuel cells enriched with domestic wastewater. Journal of Applied Microbiology, 109(3), 839-850.

17.Legendre, P., Legendre, L. 1998. Numerical Ecology. Elsevier, New York. 
18.Liu, L.H., Tsyganova, O., Lee, D.J., Su, A., Chang, J.S., Wang, A.J., Ren, N.Q. 2012. Anodic biofilm in single-chamber microbial fuel cells cultivated under different temperatures. International Journal of Hydrogen Energy, 37(20), 15792-15800.

19.Lovley, D.R. 1993. Dissimilatory metal reduction. Annual Review of Microbiology, 47, $263-$ 290.

20.Lu, L., Ren, N.Q., Zhao, X., Wang, H.A., Wu, D., Xing, D.F. 2011. Hydrogen production, methanogen inhibition and microbial community structures in psychrophilic single-chamber microbial electrolysis cells. Energy \& Environmental Science, 4(4), 1329-1336.

21.Miceli, J.F., III, Parameswaran, P., Kang, D.-W., Krajmalnik-Brown, R., Torres, C.I. 2012. Enrichment and Analysis of Anode-Respiring Bacteria from Diverse Anaerobic Inocula. Environmental Science \& Technology, 46(18), 10349-10355.

22.Picot, M., Lapinsonniere, L., Rothballer, M., Barriere, F. 2011. Graphite anode surface modification with controlled reduction of specific aryl diazonium salts for improved microbial fuel cells power output. Biosensors \& Bioelectronics, 28(1), 181-188.

23.Rabaey, K., Boon, N., Siciliano, S.D., Verhaege, M., Verstraete, W. 2004. Biofuel cells select for microbial consortia that self-mediate electron transfer. Applied and Environmental Microbiology, 70(9), 5373-5382.

24.Salvin, P., Roos, C., Robert, F. 2012. Tropical mangrove sediments as a natural inoculum for efficient electroactive biofilms. Bioresource Technology, 120, 45-51.

25.Tender, L.M., Reimers, C.E., Stecher, H.A., Holmes, D.E., Bond, D.R., Lowy, D.A., Pilobello, K., Fertig, S.J., Lovley, D.R. 2002. Harnessing microbially generated power on the seafloor. Nature Biotechnology, 20(8), 821-825.

26.Valderas, M.W., Andi, B., Barrow, W.W., Cook, P.F. 2008. Examination of intrinsic sulfonamide resistance in Bacillus anthracis: A novel assay for dihydropteroate synthase. Biochimica Et Biophysica Acta-General Subjects, 1780(5), 848-853.

27.Weber, K.A., Achenbach, L.A., Coates, J.D. 2006. Microorganisms pumping iron: anaerobic microbial iron oxidation and reduction. Nature Reviews Microbiology, 4(10), 752-764.

28.Wei, J.C., Liang, P., Huang, X. 2011. Recent progress in electrodes for microbial fuel cells. Bioresource Technology, 102(20), 9335-9344.

29. Yates, M.D., Kiely, P.D., Call, D.F., Rismani-Yazdi, H., Bibby, K., Peccia, J., Regan, J.M., Logan, B.E. 2012. Convergent development of anodic bacterial communities in microbial fuel cells. Isme Journal, 6(11), 2002-2013.

30.Yoho, R.A., Popat, S.C., Torres, C.I. 2014. Dynamic Potential-Dependent Electron Transport Pathway Shifts in Anode Biofilms of Geobacter sulfurreducens. Chemsuschem, 7(12), 3413-3419. 


\section{Figure Captions}

Figure 1. Current generated by the MFCs with different inocula over time. Dry soil from "Crater Rim" (CR, red cross), saline soil from "Church Bay" (CB, grey square) and wet soil from "Halswell River" (R, black triangles).

Figure 2. Cyclic voltammograms of the biofilms selected from the three different inocula after 29 days of enrichment (66 days for "Crater Rim"). a. and b. Turnoyer voltammograms of "Church Bay" and "River biofilms". c. Voltammograms of "Crater Rim" biofilm in turnover conditions (black lines), non-turnover conditions (grey line) and the electrolyte of "Crater Rim" MFC (black dashed line). The 3rd and 4th segments are shown on the graph.

Figure 3. Microbial community distribution for anodic communities enriched from three different inocula: Church Bay (CB), River (R) and Crater Rim (CR).

Figure 4. Power density curves for modified and unmodified anodes performed 29 days after inoculation. The power density curve of a 29 day-old "unmodified" anode grown in the same MFC configuration, at the same potential with the same inoculum is given for comparison (data from Commault et al. (2015)). This graph shows the data of one representative sample per treatment.

Figure 5. Turnover voltammograms of an unmodified anode and the modified electrodes after 29 days of selection in MFCs. Data are an average of the 3rd and 4th segments of two replicates per treatment. The voltammogram of an "unmodified" anode grown in the same MFC configuration, at the same potential with the same inoculum is given for comparison (data from Commault et al. (2015)). 


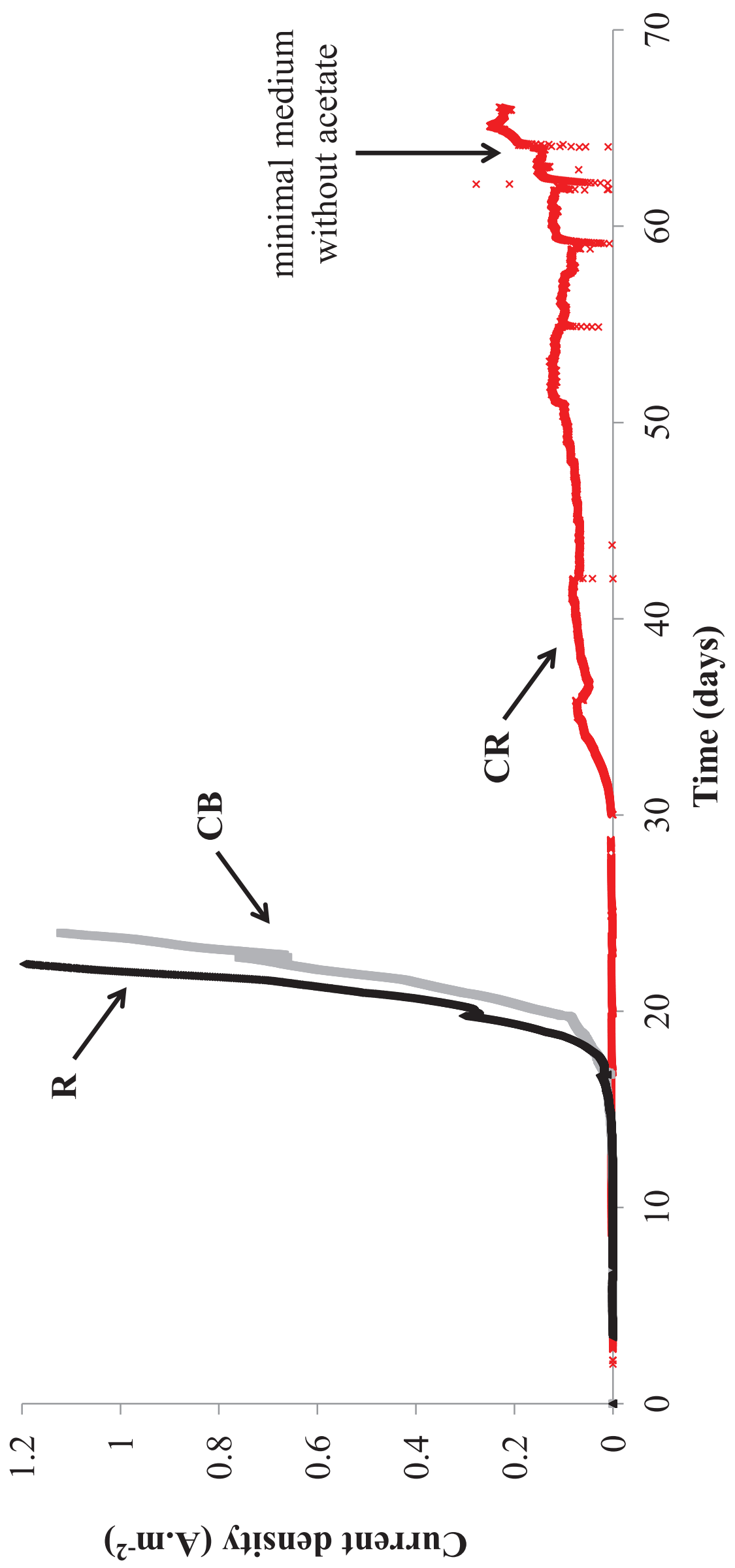




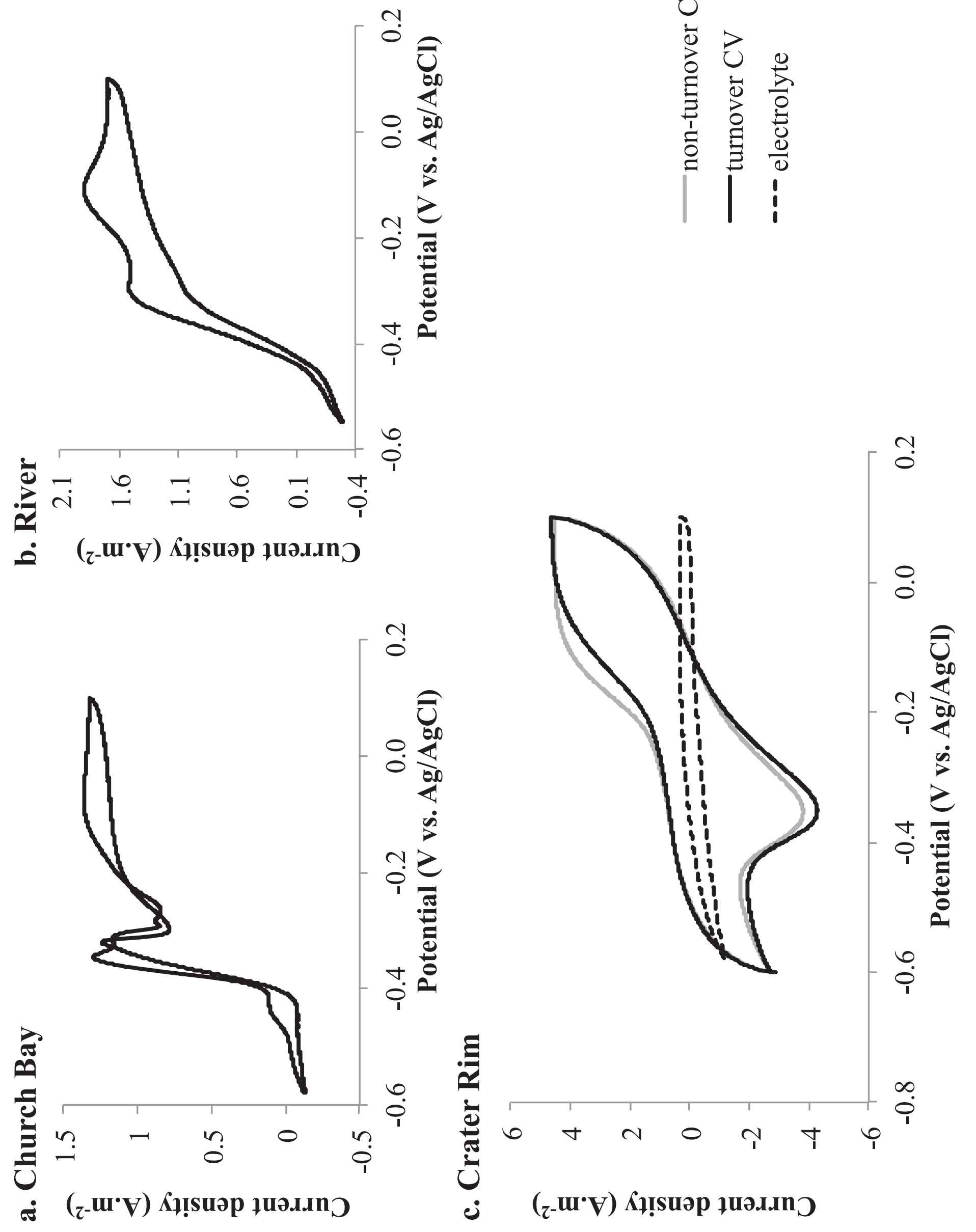



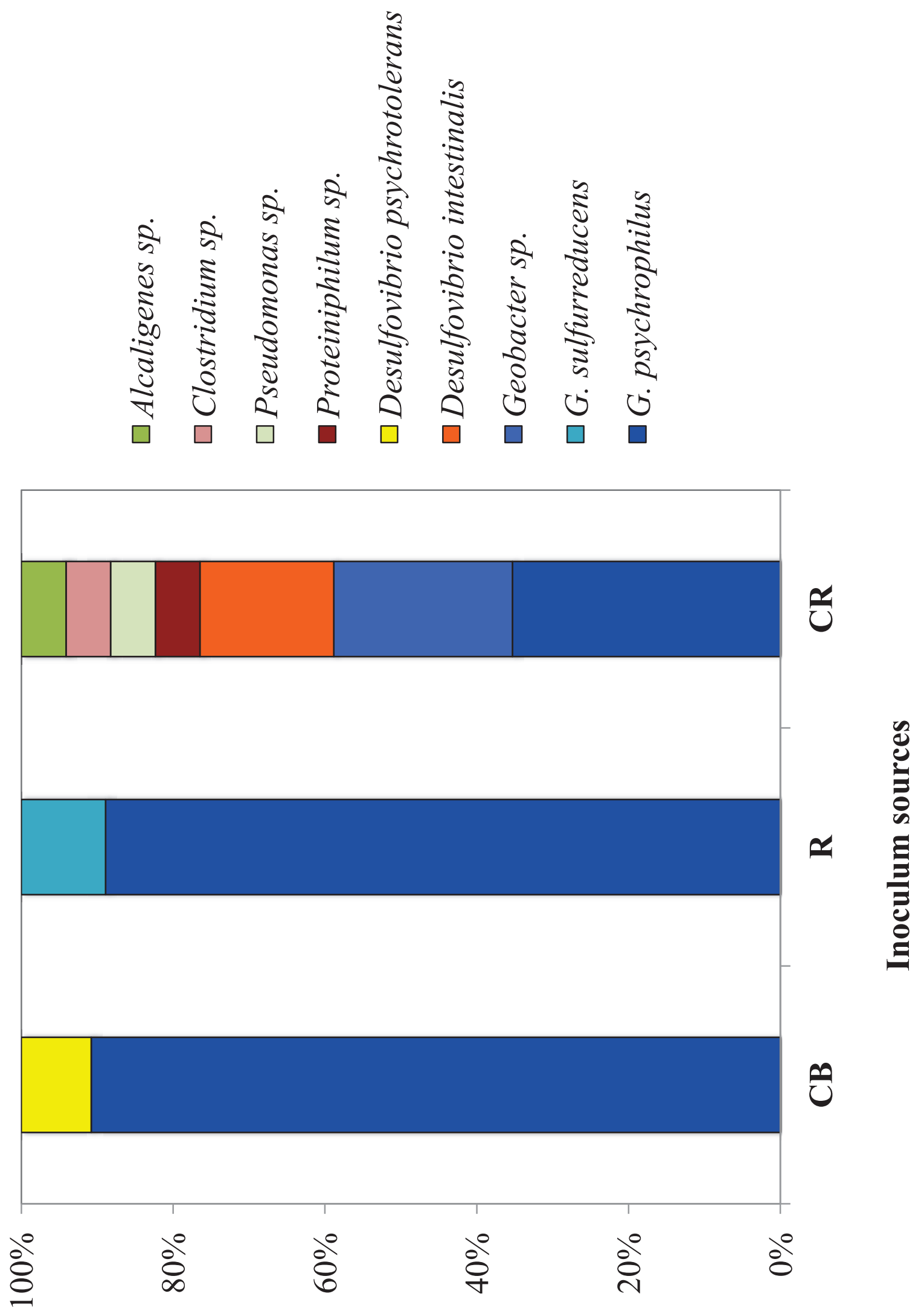

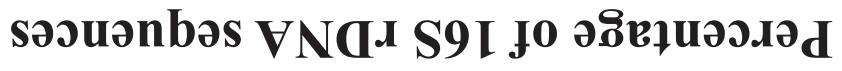




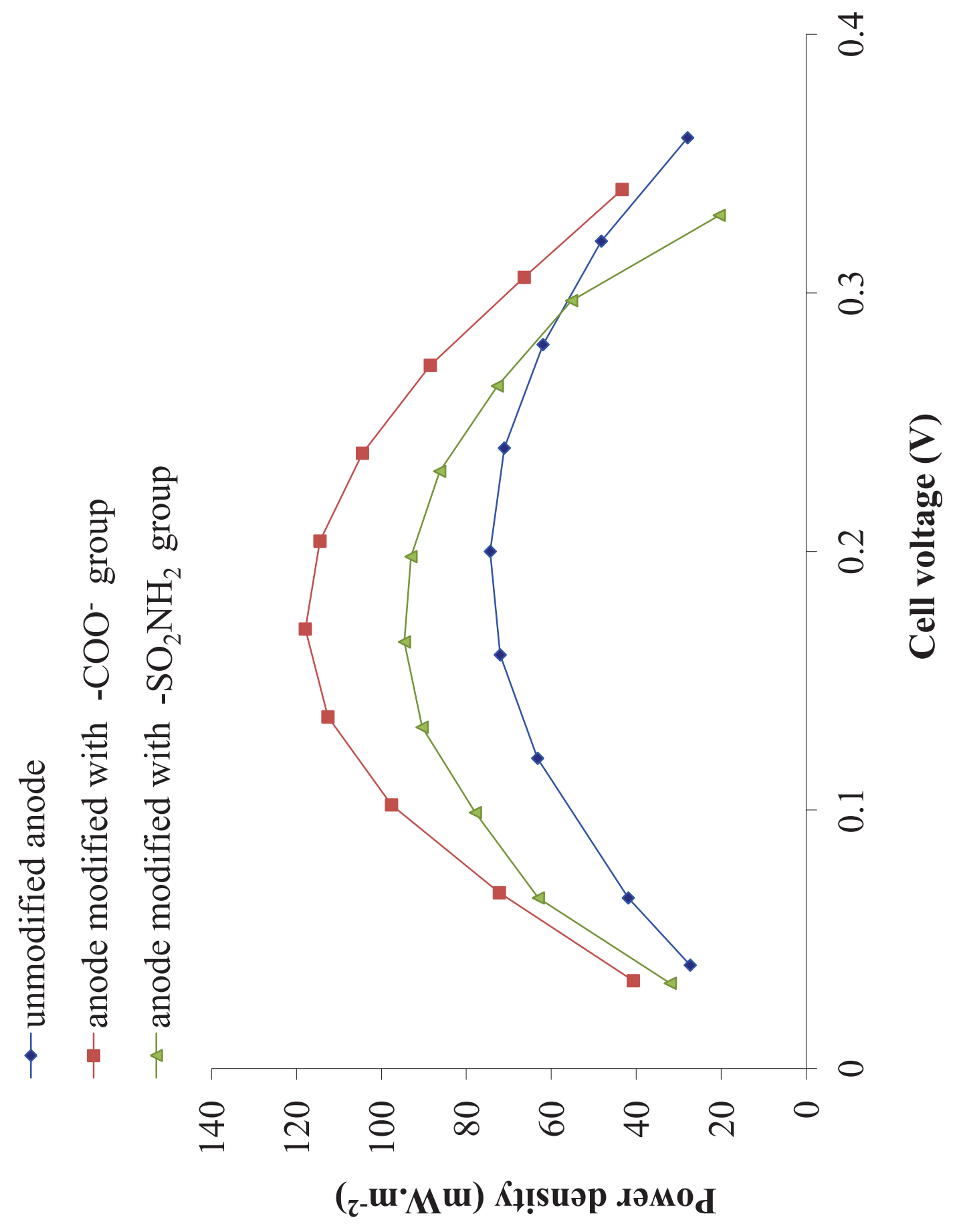




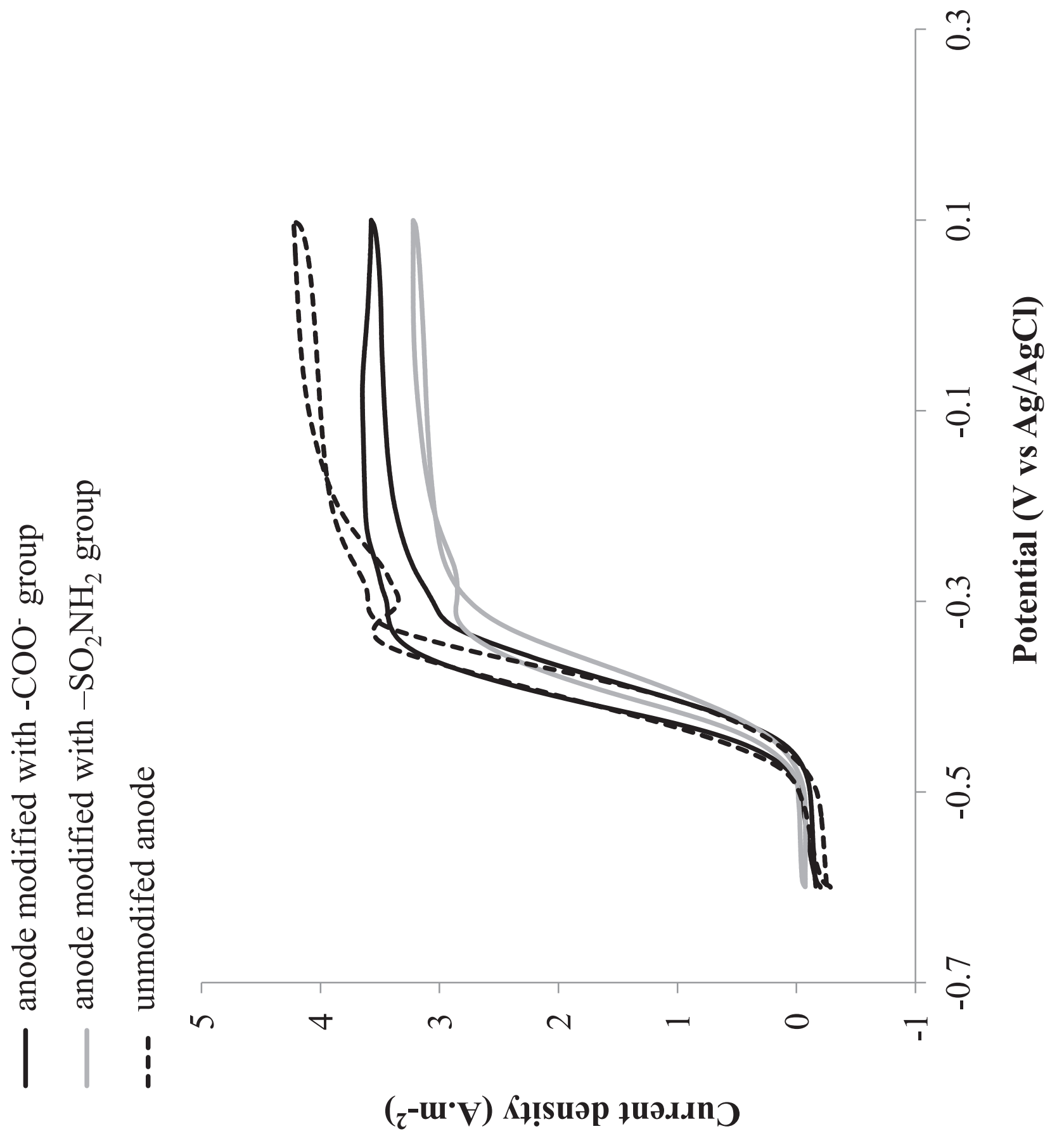




\section{Highlights}

- Dry soil MFC had longest start-up time (28 d) and poor current output

- $\mathrm{COO}^{-}$anodes had longest start-up times $(6.3 \mathrm{~d})$ but highest power output $\left(118 \mathrm{~mW} / \mathrm{m}^{2}\right)$

- All biofilms selected were dominated by Geobacter sp.

- Geobacter sp. is widespread in soils, even those frequently exposed to oxygen

- Geobacter is very much better at growing in MFC conditions than any other bacteria 